\title{
New records of Discomycetes (Pezizales) for the Chilean mycobiota
}

\section{Nuevos registros de Discomycetes (Pezizales) para la micobiota chilena}

\author{
Pablo SAndoval \\ Departamento de Sanidad Vegetal, Facultad de Ciencias Agronómicas, Universidad de Chile, Santa Rosa 11315, La Pintana, \\ Santiago, Chile. \\ Biota Gestión y Consultorías Ambientales Ltda. Miguel Claro 1224, Providencia, Santiago, Chile. \\ agropablo@gmail.com
}

\section{RESUMEN}

Se adicionan a la micobiota chilena tres especies de Pezizales, Byssonectria terrestris (Alb. \& Schwein.) Pfister, Pseudoplectania nigrella (Pers.) Fuckel y Pseudoplectania sphagnophila (Pers.) Kreisel, Se describen e ilustran los caracteres diagnósticos y se realizan comentarios acerca de las especies.

Byssonectria terrestris (Alb. \& Schwein.) Pfister, Pseudoplectanianigrella (Pers.)Fuckel and Pseudoplectania sphagnophila (Pers.) Kreisel are added to the Chilean mycobiota. Sporophores were studied and preserved following Sandoval et al. (2012). Herbarium abbreviations follow Thiers (2011).

\section{PEZIZALES}

Pyronemataceae Corda

Byssonectria terrestris (Alb.\& Schwein.) Pfister, Mycologia 85(6): 953 (1993).

Synonyms: see Pfister (1993).

Ascomata apothecial densely clustered in large groups (Fig. 1a) on an extensive whitish arachnoid subiculum (Fig. 1d), cylindrical, turbinate, up to $3 \mathrm{~mm}$ high $\times 5 \mathrm{~mm}$ wide, orange to yellow, hymenial surface smooth and a somewhat denticulate margin (Fig. 1b). Medullar and cortical excipulum textura angularis (Fig. 1f). Asci cylindrical, J-, 8-spored (Fig. 1c). Paraphyses abundant, cylindrical, upper part clavate, often curved, up $10 \mu \mathrm{m}$ wide; wall hyaline (Fig. 1c). Ascospores elliptical to fusoid, most guttulate (1-2), smooth, lateral walls thin, at apex somewhat thickened, without septa, 21-25(22) x 9-10 (9) $\mu \mathrm{m}$, hyaline, inamyloid (Fig. 1e). Ascomata release an orange pigment in $3 \% \mathrm{KOH}$.

Material examined. Chile, Región de los Ríos, Valdivia, Parque Oncol, growing on twigs and leaf litter in a young forest of Drimys winteri J.R. Forst. \& G. Forst., lat. 3941'54.88’S, long. 73¹7'59.60”W, 07-X-2008, leg. et det. P. Sandoval (SGO 161065).
ObSeRvations: Chilean collection of $B$. terrestris exactly matches descriptions given by Pfister (1993), also he points out that $B$. terrestris is a circumboreal and widely distributed species, with records known in Canada, Finland, Germany, Norway, Sweden, Switzerland and USA where it is typically found in early spring.

The literature indicates that this gregarious discomycete grows on nitrogen-enriched substrates by animal dung or urine, which may explain the appearance of the densely arranged ascomata in discrete, rather large spots at the collection site.

The suggestion of Pfister (1993) was followed, maintaining the name Byssonectria terrestris, instead Thelebolus terrestris Alb. \& Schwein, as the latter name is ambiguous. Byssonectria fusispora (Berk.) Rogerson \& Korf is a very similar species, which has been recorded in Argentina (Gamundí 1975). It differs from B. terrestris by growing in burned areas and its subiculum scanty or lacking (Pfister 1993).

\section{Sarcosomataceae Kobayasi}

Pseudoplectania nigrella (Pers.) Fuckel, Jb. Nassau. Ver. Naturk. 23-24: 324 (1870).

Synonyms: see Le Gal (1953).

Ascomata gregarious, growing on wood or soil, disc to cup shaped, sessile to substipitate, up to 15 (10) $\mathrm{mm}$ wide, (Fig. 2a), hymenium smooth, shiny, brownish-black, margin and outer surface darker and tomentose (Fig. 2a, 2b). Asci cylindrical, J-, 8-spored (Fig. 2c). Ascospores round, smooth, hyaline, 10-14 $\mu \mathrm{m}$ diam (Fig. 2d). Cortex with brownish hairs, $5-8 \mu \mathrm{m}$ broad with cells at the base, similar to P. sphagnophila, except by the stellate aspect (Fig. 2e). 


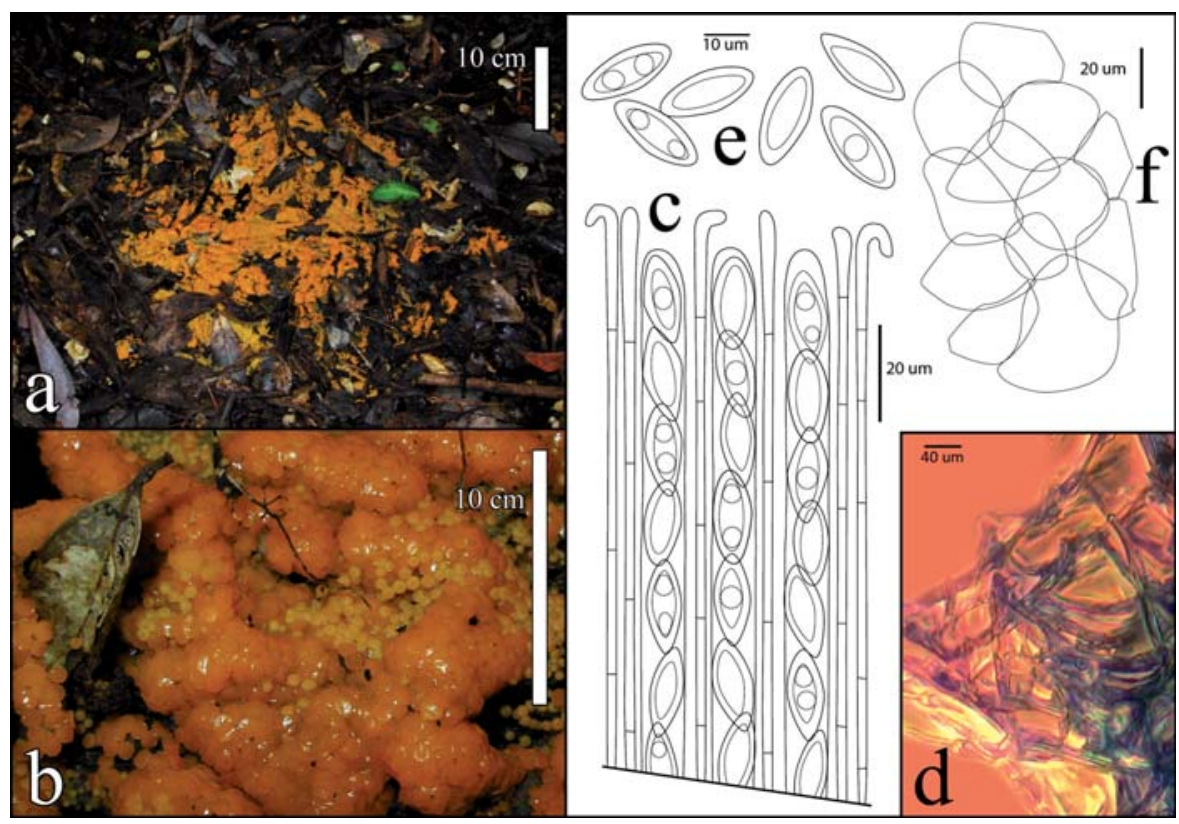

FIGURE 1. Byssonectria terrestris: a. General view of gregarious apothecia growing on leaf litter in a forest; b. Detail of densely clustered apothecia; c-f: Microscopic characters: c. Detail of hymenium showing asci and paraphyses; d. Detail arachnoid subiculum under phase contrast; e. Mature ascospores; f. Medullar exipulum detail. Pictures and drawings by P. Sandoval from SGO 161065 collection.

FIGURA 1. Byssonectria terrestris: a. Vista general de los apotecios gregarios desarrollándose sobre la hojarasca del bosque; b. Detalle de los apotecios densamente agregados; c-f: Caracteres microscópicos: c. Detalle del himenio mostrando ascos y paráfisis; d. Detalle del subículo aracnoídeo bajo contraste de fases; e. Ascosporas maduras; f. Detalle del excipulo medular. Fotografias y dibujos, por P. Sandoval a partir de colección SGO 161065.

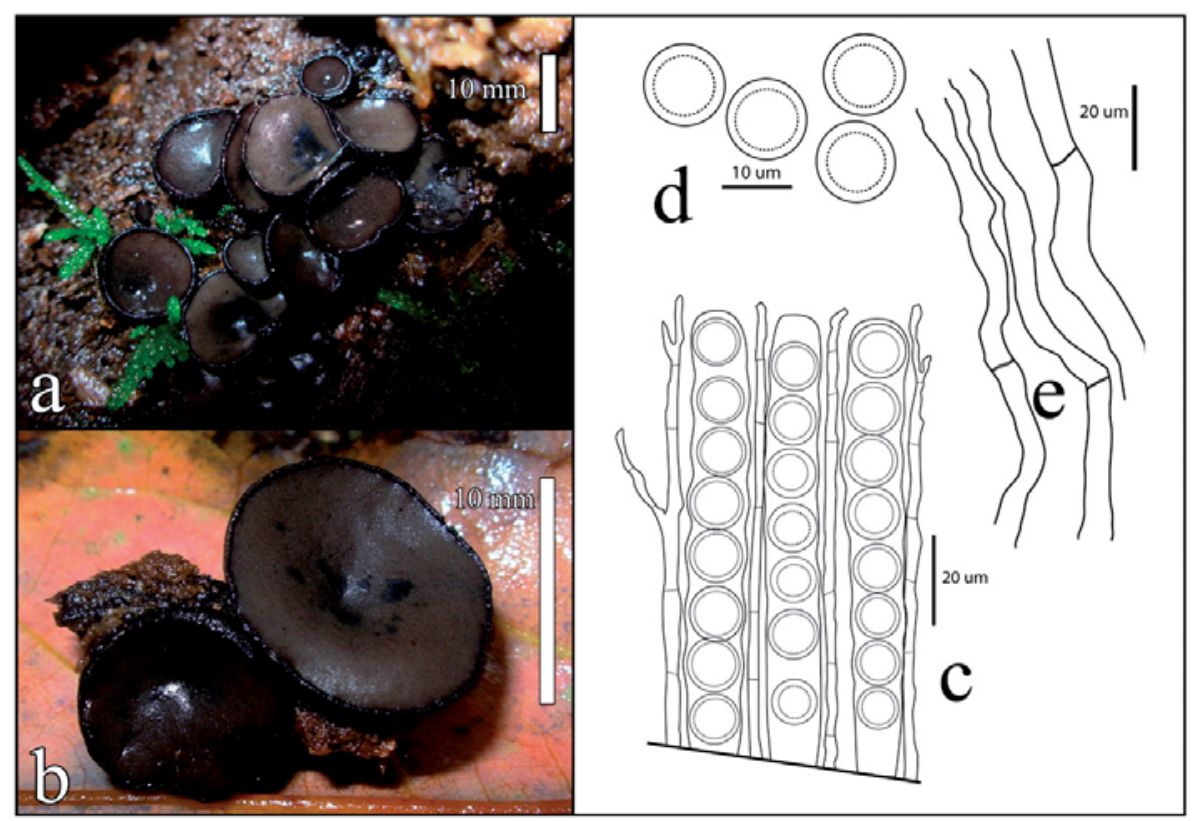

FiguRE 2. Pseudoplectania nigrella: a. Gregarious apothecia growing on decaying wood; b. Detail of apothecia; c-e: Microscopic characters: c. Detail of hymenium showing asci and paraphyses; d. mature ascospores; e. cortical hairs. Pictures and drawings by P. Sandoval from SGO 161066 collection.

Figura 2. Pseudoplectania nigrella: a. Apotecios gregarios desarrollándose sobre madera en descomposición; b. Detalle de los apotecios; c-e: Caracteres microscópicos: c. detalle del himenio mostrando ascos y paráfisis. d. ascosporas maduras. e. pelos corticales. Fotografias y dibujos, por P. Sandoval a partir de colección SGO 161066. 
Material examined. Chile, Región de Los Ríos, Ranco, Futrono, lat. $40^{\circ} 11^{\prime} 46.45^{\prime \prime} \mathrm{S}$, long. $72^{\circ} 0$ '28.64”'W, next to river Blanco around lake Maihue, growing on decaying wood in a mixed forest of Nothofagus obliqua (Mirb.) Oerst. with Nothofagus dombeyi (Mirb.) Oerst., 31-X2009, leg. J. López \& P. Sandoval, det. P. Sandoval (SGO 161066).

ObSeRvations: Chilean collection of $P$. nigrella matches the descriptions given by Breitenbach \& Kränzlin (1984), Korf \& Zhuang (1991), Kreisel (1952), Le Gal (1953), Medel et al. (2006) and Paden (1983) as well as the reported substrate (wood or soil); the species is widely distributed, being known from Europe, North America, the Caribbean (Dennis 1954), South America (Mardones-Hidalgo \& Iturriaga 2011), India, Canary Islands, Madagascar and New Zealand.

Pseudoplectania sphagnophila (Pers.) Kreisel, Westfälische Pilzbriefe 3(5): 77 (1962).

Synonyms: see Dennis (1969).

Ascomata gregarious, growing in on a Sphagnum magellanicum Brid. (Fig. 3a), cup shaped, up to $30 \mathrm{~mm}$ high and up to 20 (8) mm wide, with a short stipe, hymenium dull to black, margin and outer surface black (Fig. 3a, 3b). Asci cylindrical, J-, 275-290 x 13-14 $\mu \mathrm{m}, 8$-spored (Fig. $3 c)$. Paraphyses abundant, filiform, somewhat clavate and with dark pigments (Fig. 3c). Ascospores round, smooth, hyaline, with a large gutule, 11-12 $\mu \mathrm{m}$ diam (Fig. 3d). Cortical hairs brownish, septate, up $200 \mu \mathrm{m}$ long., with stellate aspect at the base due to groups of dark brown cells in that place (Fig. 3e).

Material examined. Chile, Región de Los Lagos, Llanquihue, Puerto Montt, south of Puerto Montt city, beside "La

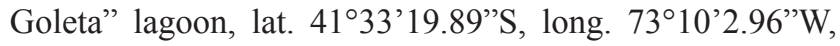
in a Sphagnum bog with presence of Nothofagus antarctica (G. Forst.) Oerst, growing on Sphagnum magellanicum Brid. (det. Juan Larraín), 08-IX-2011, leg. P. Sandoval \& J.H. Márquez, det. P. Sandoval (SGO 161067).

ObSERvations: Chilean material of $P$. sphagnophila matches descriptions given by Breitenbach \& Kränzlin (1984), Favre (1948), Kreisel (1952) and comments by Dennis (1969). Also, the species is known as Pseudoplectania nigrella var. episphagnum J. Favre and it has been recorded in Bulgaria (Dimitrova \& Assyov 2004), Germany, South Ireland and Switzerland, growing only on Sphagnum spp.

Pseudoplectania vogesiaca Seaver is a similar species, but it differs from $P$. sphagnophila by growing on wood or ground and from $P$. nigrella by its true stalk; microscopically $P$. vogesiaca differs by the spirally curved tips of paraphyses.

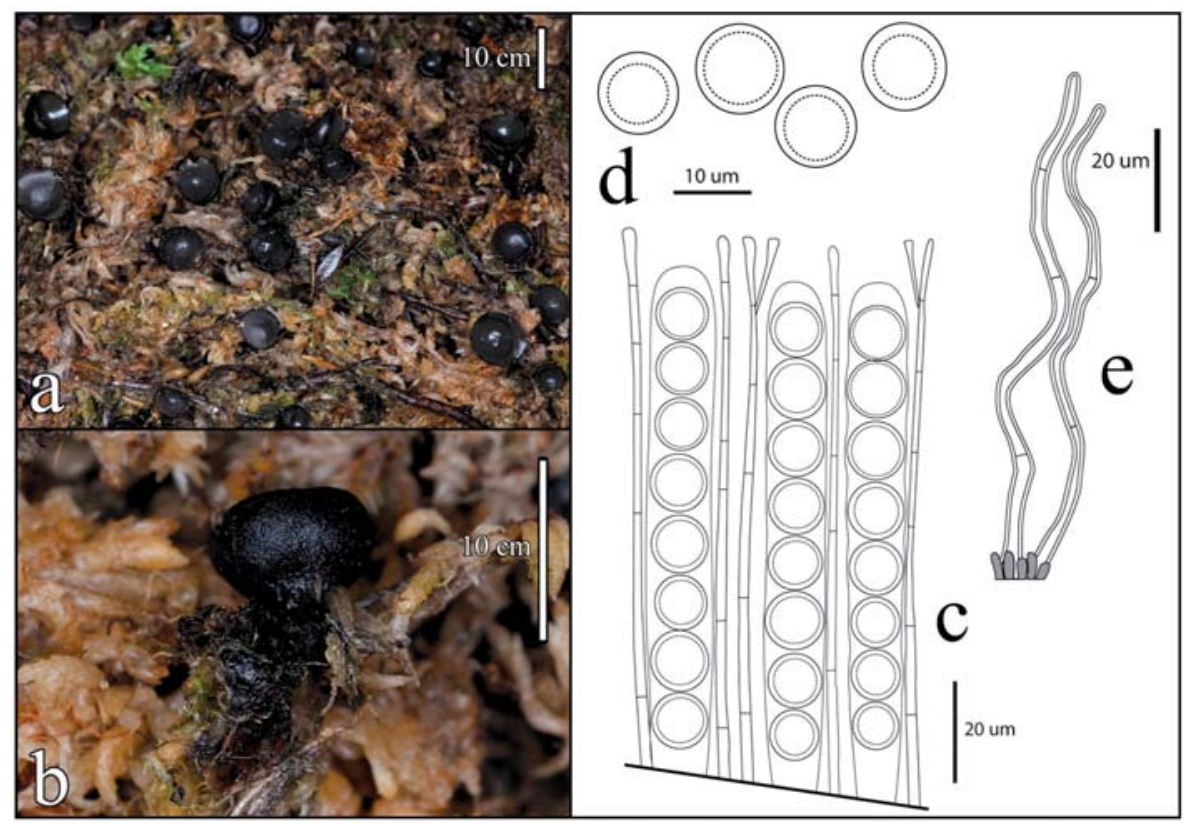

Figure 3. Pseudoplectania sphagnophila: a. Gregarious apothecia growing on Sphagnum magellanicum; b. Lateral view of an ascoma, showing stipe with dark hairs; c-e: Microscopic characters: c. Detail of hymenium showing asci and paraphyses; d. Mature ascospores; e. Cortical hairs. Pictures and drawings by P. Sandoval from SGO 161067 collection.

Figura 3. Pseudoplectania sphagnophila: a. Apotecios gregarios desarrollándose sobre Sphagnum magellanicum; b. Vista lateral de un ascoma, mostrado el estipe con pelos oscuros; c-e: Caracteres microscópicos: c. Detalle del himenio mostrando ascos y paráfisis; d. Ascosporas maduras; e. Pelos corticales. Fotografías y dibujos, por P. Sandoval a partir de colección SGO 161067. 
Plectania and Pseudoplectania differ basically by their spore shape, with spores of Plectania not being spherical. Korf (1972), however, points out that Plectania spores can also be spherical during early ontogeny and may remain so for a long time. Following this last criterion, many authors as Paden (1983), Medel \& Chacón (2000) and Korf \& Zhuang (1991) suggest including Pseudoplectania in Plectania. However, recent ultrastructural studies (TEM) on ascospores of Pseudoplectania nigrella and Plectania nannfeldtii Korf (Li \& Kimbrough 1995) show that ascospores of pseudoplectania lack a secondary wall layer, instead ascospores of Plectania has secondary spore wall ornamentation that is cyanophilic under a light microscope. Due to this background, it was preferred to maintain both genera separate, following the criteria used by Dennis (1978).

It worth to say that these three species, Byssonectria terrestris, Pseudoplectania nigrella and Pseudoplectania sphagnophila seem to be reported for the first time, not only for Chile as well as for Southern Cone of South America. They were mentioned by neither Gamundí (1975, 2010, et al. 2004, among others) nor Spegazzini (1887a, 1887b, 1910, 1921, among others). Even more, after an exhaustive literature review, only it was found records of $P$. nigrella from Venezuela (Mardones-Hidalgo \& Iturriaga 2011) for South America.

\section{ACKNOWLEDGEMENTS}

I am grateful to José Luis Henríquez and Luis Faúndez, for their help and advice, to Irma Gamundí, Andrea Romero and Beñat Jeannerot for their advices and help with literature, to Gustavo Cabello and Felix Hidalgo for geographic data and to Parque Oncol administration, especially to Pablo Lépez for all the working facilities in the park.

\section{REFERENCES}

Breitenbach, J. \& F. Kränzlin. 1984. Fungi of Switzerland. Volume 1: Ascomycetes. Luzern, Switzerland: Verlag Mykologia. $310 \mathrm{pp}$.

DenNIS, R.W.G. 1954. Operculate Discomycetes from Trinidad and Jamaica. Kew Bulletin 9(3): 417-421.

DennIs, R.W.G. 1969. Two New British Discomycetes with Smooth Spherical Ascospores. Kew Bulletin 23(3): 479-481.

Dennis, R.W.G. 1978. British Ascomycetes. J. Cramer, Vaduz. 585 pp.

Dimitrova, E. \& B. Assyov. 2004. New data for Pezizales in Bulgaria. Mycologia Balcanica 1(1): 1-3.

FAVRE, J. 1948. Les associations fongiques des hauts-marais jurassiens et de quelques régions voisines. Matériaux pour la Flore Cryptogamique Suisse 10(3): 1-228.
Gamundí, I.J. 1975. Fungi, Ascomycetes, Pezizales. En: Flora criptogámica de tierra del fuego, tomo $\mathrm{X}$, fasc. 3. FECICCONICET, Buenos Aires, Argentina. 185 pp.

Gamundí, I.J. 2010. Genera of Pezizales of Argentina 1. An updating of selected genera. Mycotaxon 113: 1-60.

Gamundí, I.J., D.W. Minter, A.I. Romero, V.A. Barrera A.L. Giaiotti, M.I. Messuti \& M. Stecconi. 2004. Checklist of the Discomycetes (Fungi) of Patagonia, Tierra del Fuego and adjacent Antarctic areas. Darwiniana 42(1-4): 63-164.

Kirk, P.M., P.F. Cannon, D.W. Minter \& J.A. Stalpers. 2008. Dictionary of the fungi. 10th Edition. CAB International, Wallingford. $771 \mathrm{pp}$.

Korf, R.P. 1972. Synoptic Key to the Genera of the Pezizales. Mycologia 64(5): 937-994.

Korf, R.P. \& W-Y. ZhuAng. 1991. A preliminary Discomycete flora of Macaronesia: Part 11, Sarcoscyphineae. Mycotaxon 40: $1-11$.

Kreisel, H. 1952. Pilze der Moore und Ufer Norddeutschlands, III. Pseudoplectania sphagnophila (Fr. pro var.) Kreisel nov. comb. Westfälische Pilzbriefe 3(5): 74-78.

Le GaL, M. 1953. Les Discomycètes de Madagascar. Prodrome à Flore Mycologique de Madagascar et Dépendances 4: 1465.

Li, L-T \& J.W. Kimbrough. 1995. Spore wall ontogeny in Pseudoplectania nigrella and Plectania nannfeldtii (Ascomycotina, Pezizales). Canadian Journal of Botany 73: 1761-1767.

Mardones-Hidalgo M. \& T. Iturriaga. 2011. Diversity and substrate partitioning of Discomycetes in a cloud forest in Venezuela. Mycosphere 2(6): 617-625.

Medel, R. \& S. Chacón. 2000. Contribución al conocimiento del género Plectania (Pezizales, Sarcosomataceae) en México. Acta Botánica Mexicana 50: 11-19.

Medel, R., F. Calonge \& G. Guzmán. 2006. Nuevos registros de Pezizales (Ascomycota) de Veracruz. Revista Mexicana de Micología 23: 83-86.

Paden, J.W. 1983. Sarcosomataceae (Pezizales, Sarcoscyphineae). Flora Neotropica 37: 1-16.

Pfister, D.H. 1993. A synopsis of the North American Species of Byssonectria (Pezizales) with Comments on the Ontogeny of Two Species. Mycologia 85(6): 952-962.

Sandoval, P., J.L. Henríquez, L. Faúndez \& J. Larraín. 2012. First records of Eocronartium muscicola (Basidiomycota, Eocronartiaceae) in Chile on two new hosts. Gayana Botánica 69(2): 100-104.

Spegazzini, C.L. 1887a. Fungi Patagonici. Boletín de la Academia Nacional de Ciencias Córdoba 11(1): 5-64.

Spegazzini, C.L. 1887b. Fungi Fuegiani. Boletín de la Academia Nacional de Ciencias Córdoba 11(2): 135-311.

Spegazzini, C.L. 1910. Fungi Chilenses. Contribución al Estudio de los Hongos Chilenos. Revista de la Facultad de Agronomía y Veterinaria, Universidad Nacional de La Plata ep. 2,6(1): $1-205$.

Spegazzini, C.L. 1921. Mycetes Chilenses. Boletín de la Academia Nacional de Ciencias Córdoba 25: 1-124.

ThIERs, B. Continuously updated. Index Herbariorum: A global directory of public herbaria and associated staff. New York Botanical Garden's Virtual Herbarium. http://sweetgum. nybg.org/ih. Access date: November 2011.

Recibido: 13.12 .11

Aceptado: 06.07.12 